\title{
Peripécias da identidade em um relato de Adolfo Bioy Casares. Notas de trabalho sobre La invención de Morel ${ }^{1}$
}

Miriam V. Gárate

\author{
Hoje, nesta ilha, ocorreu um milagre: o verão antecipou-se. Pus a cama perto da \\ piscina e fiquei tomando banho até muito tarde... Dois ou três minutos fora basta- \\ vam para converter em suor a água que devia me proteger... ${ }^{2}$ (25)
}

A metamorfose da água em suor anuncia um tópico que, metamorfoseado por sua vez, reaparecerá e se desdobrará em diversas instâncias do relato: o da transformação do uno em seu aparente igual (forma da duplicação) mas, de fato, ou em outro plano, em seu contrário. Pois, como o olhar poderia discernir, na mesma gota que desliza pela superfície do corpo, entre aquilo que emana do interior e o que provém de fora, entre o líquido que é obra do calor e o solicitado para refrescar, entre a toxicidade da transpiração e a pureza da água? ${ }^{3}$ Transparentes ambos, escorregando ambos na pele, água e suor dão-se a ver como sendo o mesmo (embora não o sejam) numa primeira cena na qual o leitor ocupa o mesmo lugar, sem sabê-lo ainda, que ocupa o narrador com respeito ao conjunto de veranistas surgidos do nada. O leitor vê banhar-se alguém, que poucos parágrafos mais tarde vê banhando-se um grupo de desconhecidos: "Tenho certeza de que não chegou nenhum barco... E, contudo, de um momento para o outro, os capinzais da colina cobriram-se de pessoas que dançam, passeiam e tomam banho na piscina como veranistas instalados desde há muito tempo em Los Teques ou em Marienbad" (26). Voyeur o leitor, voyeur o narrador-protagonista; duplamente voyeur o leitor. ${ }^{4}$ 
De fato, numa primeira instância, o olhar clandestino, de mão única (condição inerente à atividade do voyeur) adequa-se à condição do perseguido, resguardando-o. Mas a pulsão escópica, cada vez mais forte, vai metamorfosear essa lógica primeira fazendo daquele que, para sobreviver, não pode nem deve ser visto, aquele que para viver buscará com desespero o olhar do outro, desejará chamar sua atenção a qualquer preço. Em outras palavras: o voyeur se tornará exibicionista - inutilmente, sabemos, já que sua imagem será ainda mais translúcida que a água ou o suor diante dos olhos "cegos" de Faustine (a vã tentativa funcionará como disparadora de uma cadeia de imitações, poses, duplicações etc. da qual me ocuparei mais adiante).

Fugir do olhar dos outros, por perseguido; fugir a uma ilha ("mas nesse lugar não se vive", advertira o italiano de Calcutá) $;{ }^{5}$ perseguir com o olhar de uma posição oculta e hipoteticamente protegida num segundo momento ("contemplo, com alguma fascinação - há tanto tempo que não via gente! - esses abomináveis intrusos”); exibir-se em vão para recuperar a visibilidade perdida mais tarde; entregar-se à simulação e no mesmo ato à morte (com aparências de vida) depois de um paciente ensaio, para que outro voyeur, imaginado o previsto, veja o que não é. Para que ele confunda, como se confundem suor e água nas primeiras linhas do romance, o falso encontro entre o narrador e Faustine com um encontro real. Eis os principais avatares deste jogo no qual a identidade (dos sujeitos, de seus sentimentos e suas experiências) dirime-se em grande medida através desses "espelhos da alma" que são os olhos ${ }^{6}$.

Conjugado com a temática apontada também surge nas primeiras linhas o insólito: a milagrosa antecipação do verão, a rara vegetação do lugar, o fonógrafo que soa repentinamente na madrugada, a aparição inexplicável de um extravagante grupo de homens e mulheres ("estão vestidos com roupas iguais às que se usavam há poucos anos", "dançam 
entre os capinzais da colina, ricos em víboras"), as não menos extravagantes construções da parte alta da ilha: o museu, a capela, a piscina "cheia de víboras, sapos, rãs". Dos três edifícios, o de maior interesse para o protagonista (e para o leitor) é o primeiro:

\footnotetext{
Encontrei-o aberto e logo me instalei nele. Chamo-o de museu porque assim o chamava o mercador italiano... Tem um hall com estantes inesgotáveis e deficientes: não há mais do que romances, poesia, teatro, excetuando-se um livrinho -Belidor: travaux - Le moulin perse. Paris, 1737 [...] Tomei-o porque o nome Belidor me pareceu estranho [...] Percorri as estantes, procurando ajuda para certas investigações que o processo interrompeu e que, na solidão da ilha, tentei continuar. Creio que perdemos a imortalidade porque a resistência à morte não evoluiu; seus aperfeiçoamentos insistem na primeira idéia, rudimentar: reter vivo o corpo todo. Só deveria buscar-se a conservação do que interessa à consciência. (28)
}

Desnecessário deter-se no momento na obediência observada em relação às convenções do fantástico. Baste mencionar por enquanto que vários de seus elementos constitutivos introduzirão, desde o início, o motivo da proliferação de (aparentes) iguais: o salão redondo do museu possui "um biombo de espelhos que tem vinte folhas ou mais"; o primeiro subsolo do museu desdobra-se num segundo, protegido por uma porta secreta que o narrador consegue burlar e no qual se depara com "uma câmara poliédrica" em cujo interior vê, por sua vez, "em oito direções se repetir, como em espelhos, oito vezes a mesma câmara", depois do que ouve "muitos passos, terrivelmente claros" a seu redor, que cessam de repente ("Apagaram-se os ruídos... Havia o silêncio... Temi uma invasão de fantasmas, uma invasão de policiais, menos inverossímil... Pela madrugada desci de novo ao porão. Rodearam-me os mesmos passos... Mas desta vez compreendi. Molesto, continuei a percorrer o segundo porão intermitentemente escoltado por uma bandada solícita de ecos....") (30-1). Contudo, a duplicação mais importante que se institui nessa primeira incursão ao museu é a que faz do narrador-protagonista 
uma espécie de duplo antecipado (e por enquanto inconsciente) de Morel. Como Morel, ele dedicou-se a certas investigações sobre a imortalidade interrompidas pela fuga, retomadas na solidão da ilha ("tentei continuar...") e que norteiam sua busca nas estantes da biblioteca. Procura-se um livro; encontrar-se-á uma mulher.

"Nas rochas há uma mulher olhando os pores-do-sol, todas as tardes. Tem um lenço..." (31). O leitor olha o narrador-protagonista que olha a mulher olhando, fenômeno que introduz um grau a mais (e um elemento a mais) no jogo. O narrador, que não esperava nada, passa a esperar a presença da mulher e, com isso, embora timidamente ainda, uma reversão no circuito: "Não espero nada. Isso não é horrível. Depois de aceitálo ganhei tranquilidade. Mas esta mulher me deu uma esperança. Devo temer as esperanças. Olha os pores-do-sol todas as tardes; eu, escondido, a olho... descobri que minhas noites e meus dias esperam por essa hora... sinto, talvez um pouco de brincadeira, que se pudesse ser olhado um instante, falado um instante por ela, afluiria [...] o socorro que encontra o homem nos amigos, nas namoradas..." (31).

A irrupção da figura feminina acrescenta, portanto, aos registros do relato de suspense ou de aventuras ("Talvez esteja preparando uma estupidez irremediável: talvez esta mulher acalentada por sóis... me entregue à policia..”) e do relato fantástico (“esta gente desaparecerá; talvez tive alucinações"), o registro da intriga amorosa: "Agora a mulher do lenço resulta-me imprescindível. Talvez toda essa higiene de não esperar seja um pouco ridícula. Nada esperar da vida, para não arriscá-la; dar-se por morto para não morrer. [...] Começou há oito dias. Registrei então o milagre da aparição dessas pessoas. [...] Disse para mim mesmo que tudo era vulgar: o tipo boêmio da mulher e minha paixão, própria de solitário acumulado. Voltei mais duas tardes: a mulher estava; comecei a achar que o único milagre era esse" (34). 
No cruzamento ou interseção de dois milagres - um atribuível ao plano do fantástico, outro à lógica talvez não menos fantástica do desejo - arma-se uma trama que, em aparência, passa a centrar-se nos avatares da conquista amorosa: como chamar a atenção?; como devir objeto de uma paixão que somente se pode materializar se dois olhares intersetamse?

Transcrevo in extenso as principais passagens do início desta história de amor:

Depois de tomar banho... fui vê-la. Tinha traçado este plano: esperá-la nas rochas; a mulher, ao chegar, me encontraria abstraido no pôr-do-sol; a surpresa, o receio... teriam tempo de se transformar em curiosidade... ela me perguntaria quem sou; nos tornariamos amigos... Cheguei tarde demais [...] Estraguei tudo: ela contemplava o entardecer e bruscamente surgi detrás de umas pedras.... Esta mulher é algo a mais que uma falsa cigana. Espanta-me sua coragem. Nada anuncion que me tivesse visto. Nem um pestanejar, nem um leve sobressalto (35).

Eu tinha escalado com urgência as pedras. Vi-a [...] Então, para adiar o momento de lhe falar descobri uma antiga lei psicológica. Convinha-me falar de um lugar alto (para compensar em parte minhas inferioridades). Subi outras rochas. O esforço piorou meu estado. Pioraram-no também: a pressa... Vế-la: como se posasse para um fotógrafo invisivel, tinha a calma do entardecer porém mais imensa. Eu ia interrompê-la... Olhei-a, escondido. [...] apareci, talvez demasiado bruscamente, diante de seu olhar; no entanto, a paz de seu peito não se interrompeu; os seus olhos prescindiam de mim como se eu fosse invisivel... - Senhorita, quero que me ouça... Insisti: - compreendo que não se digne. Não posso lembrar, com exatidão, o que disse... Renunciei às palavras e pus-me a olhar o poente, esperando que a compartilhada visão dessa calma nos aproximasse. Voltei a falar-lhe ... Insisti, implorei, de um modo repulsivo. No fim, fui excepcionalmente ridículo: trê- 
mulo, quase aos gritos, pedi-lhe que me insultasse, que me delatasse, mas que não continuasse em silêncio. Não foi como se não me tivesse ouvido, como se não me tivesse visto; foi como se os ouvidos que tinha não servissem para ouvir, como se os olhos não servissem para ver. De certo modo insultou-me, demonstrou que não me temia (36).

Foi outra vez, como se não me tivesse visto. Não cometi outro erro que o de permanecer calado [...] Quando a mulher chegou às tocas eu olhava o poente. [...] Teria bastado esticar o braço para tocá-la. Esta possibilidade me horrorizou (como se tivesse corrido o risco de tocar um fantasma). Naquele seu prescindir de mim havia algo espantoso... Tirou o livro... e ficou lendo... Depois, quando a vi largar o livro, levantar os olhos, pensei: prepara uma interpelação. Isto não ocorreu.... (36).

O desejo de "se mostrar" gera uma série de empresas imaginárias (espécie de ensaio mental preparatório de atos posteriores) fundadas no mimetismo, na imitação, na duplicação da postura do outro. Primeiro traça-se o plano de "posar como para um fotógrafo invisível": "ao chegar [a mulher] me encontraria abstraído no pôr-do-sol”. Arruinado devido à impontualidade do narrador, esse plano cede lugar, por um momento, à improvisação. Irrompe bruscamente diante da mulher (aparição não menos brusca que a do grupo de veranistas e da própria mulher mas, à diferença desta, inócua, já que a primeira transtorna o protagonista e torce o curso de seu destino; a segunda, ao contrário, rebate contra os ouvidos surdos e os olhos cegos de Faustine). Roga, suplica em vão. Depois do que se retoma e realiza-se o projeto inicial: "quando a mulher chegou às tocas eu olhava o poente".

Embora caiba afirmar que no plano "objetivo" os efeitos são nulos, no plano subjetivo, a usurpação provisória do lugar da mulher propicia um desdobramento do narrador que pensa e vê por si ao mesmo tempo que por ela. Graças a esse equívoco se forja uma alteridade, vislumbram-se intenções, é-se de algum modo os dois: "quando a vi largar 
o livro, levantar, os olhos, pensei: prepara uma interpelação. Isto não ocorreu.... Que a mulher volte, a proximidade que procurou, tudo parece indicar uma mudanca demasiado feliz para que eu possa imaginá-la" (37). (Difícil eludir a tentação de metamorfosear a cláusula: impossível que eu possa imaginar tudo. A longo prazo, a impossibilidade de fato será revelada; sem a mínima colaboração de um outro a cena torna-se literalmente inimaginável).

Esse primeiro ato de projeção tem continuidade num conjunto de peripécias que ridicularizam os lugares-comuns da paixão amorosa. $\mathrm{O}$ tradicional envio de flores transmuda-se num vergonhoso projeto de jardim que tem a forma de "uma imensa mulher, sentada, contemplando o entardecer [...] e de um homem exíguo feito de folhas", enriquecido por uma série de inscrições sucessivamente revistas e modificadas. Faustine passa ao lado desse "jardinzinho de mau gosto", reconhece o artífice, "mas simula não vê-lo". A esse episódio sucede o primeiro de um conjunto que daqui por diante irá pautar os avatares da paixão inscrevendo-os sob o signo da triangularidade e, portanto, dos ciúmes, da suspeita, do assédio, das recriminações:

Hoje a mulher quis que eu sentisse sua indiferença. Conseguiu-o. Mas sua tática é desumana... Veio com o horroroso tenista... Escondi-me imediatamente. Ignoro se ela me viu; suponho que sim, porque em nenhum momento pareceu procurar-me com o olhar. [...] Ouvi algumas exclamações francesas... - Acredite, Faustine - disse o barbudo com desespero mal contido, e eu soube o nome: Faustine... Sorria, sem amargura nem êxtase, frivolamente. Lembro que naquele momento a odiei. Brincava com o barbudo e comigo... Certamente, é uma mulher detestável. Mas, o que pretende? Talvez brinque comigo e com o barbudo; mas também é possível que o barbudo não seja mais que um instrumento para brincar comigo. Fazê-lo sofrer não lhe importa. Talvez Morel não seja mais que uma ênfase em seu prescindir de $\operatorname{mim}^{8}(40-2)$. 
Aprisionado numa rede crescente de especulações, o protagonista lê cada gesto e reinterpreta cada cena com uma cegueira fundamental. $\mathrm{O}$ jogo da ilusão começa a girar em falso (pois só gira sobre si) embora ainda nem o protagonista nem o leitor o saibam.

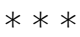

Enredando-se com o amoroso (com os pormenores de um amor "não correspondido"), desponta o mistério da repetição: "Minha decisão de não aparecer diante de Faustine durou quatro dias... chegaram Faustine e o falso tenista... Notei que já não se tratavam por "tu"; mas logo lembrei que quando as pessoas começam a se tratar por tu, não podem evitar os retornos ao 'o senhor'. Talvez pensei isso influenciado pela conversa que estava ouvindo. Tinha, também, essa idéia de volta ao passado, mas referida a outros temas... [Morel] continuava com os mesmos rogos que eu tinha ouvido oito dias antes... As conversas se repetem; são injustificáveis [...] Com lentidão na minha consciência, pontuais na realidade, as palavras e os movimentos de Faustine e do barbudo coincidiram com suas palavras e seus movimentos de havia oito dias. [...] Como no teatro, as cenas se repetem. Ao ouvir a Faustine e ao barbudo eu corrigia minha lembrança da conversa anterior" (42-4).

A reiteração intuída no plano do real (na realidade da ficção) se duplica no telão da mente: Morel repete os mesmos rogos, Faustine os mesmos movimentos; o narrador repete em sua consciência movimentos e gestos de um e de outro (o artífice da história, por sua vez, repete literalmente as mesmas palavras). Para quebrar esse círculo e dar alimento a sua esperança através de uma mudança de posição (de uma diferença) , o narrador-voyeur irrompe espontaneamente?

Tinha começado a sentir vontade de castigar esse indivíduo... de afrontá-lo... O barbudo foi procurar o lenço e a sacola de Faustine. Retornava, dizendo, como da outra vez: - Não leve a sério... Eu apareci, muito decidido a qualquer coisa, mas a 
nada em particular. A espontaneidade é fonte de grosserias. Assinalei o barbudo, como se o estivesse apresentando a Faustine, e disse-lhe aos gritos - La femme à barbe, Mme Faustine!... O barbudo seguiu caminhando [...] e não tropeçou comigo porque me desviei, rapidamente. A mulher não interrompeu as perguntas; não interrompen a alegria de seu rosto. Sua tranquilidade ainda me aterroriza [...] $O$ que acontece não tem explicaşão. A colina está desabitada (44).

A evolução do drama amoroso (tentativas fracassadas, ciúmes crescentes, esboço de novas estratégias) e a progressão de fatos inexplicáveis (desaparecimento e reaparição súbita de Faustine, Morel, bem como de outros veranistas; proximidade iminente com alguns deles seguida de notória indiferença por parte dos mesmos; ressurgimento dos pescados podres retirados da piscina com antecipação etc.) urdiram nessas alturas uma trama compacta que entrelaça mistérios de duas ordens. Elucidar "se os pés de Morel e os de Faustine se tocam" por baixo da mesa - atividade à qual o narrador consagra "uns minutos, quem sabe muitos, insensível a tudo" - não é menos árduo que determinar "como e quando esses sujeitos chegaram à ilha", ou menos inquietante que "caminhar retesado entre eles" sem ser notado, e ver "dois sóis e duas luas" no dia seguinte ao segundo aparecimento dos mesmos. Temporariamente, porém, o relato passa a concentrar-se na dimensão fantástica da experiência, propondo diversas hipóteses explicativas até encontrar a solução do enigma, o que permitirá retomar definitivamente o enigma de uma máquina não inventada por Morel, nem pelo narrador, nem pelo leitor, porém que os faz funcionar a todos e os reinventa em cada ato - a máquina do desejo.

Algumas considerações acerca do registro especificamente fantástico da narrativa que podem contribuir para um melhor entendimento de sua trajetória final, bem como do desenlace. 
Se se pensa nas características do fantástico tradicional, tal como foram definidas por alguns de seus principais teóricos, ${ }^{10}$ cabe afirmar que La invención se adequa em linhas gerais às regras do gênero. $\mathrm{O}$ andar do texto estabelece desde o início um vaivém entre irrupção do extraordinário/dúvida/hipóteses explicativas, concomitante com a oscilação entre enunciados figurados e literais - isto é, dados a ler como figurados num primeiro momento e tornados literais numa segunda instância. À medida que o relato avança, a multiplicação de fenômenos excepcionais e a dúvida crescente que eles engendram levam a ampliar o leque de hipóteses possíveis em direção ao maravilhoso, de acordo com a nomenclatura consagrada por Todorov. Assim, pouco antes de ser testemunha da declaração de Morel, o narrador ensaia as seguintes explicações: a) ter contraído a "famosa peste", que traria "consequências na imaginação" (alucinações) e posteriormente no corpo (decomposição e morte); b) ter-se tornado invisível devido ao "ar pervertido dos baixos e a uma deficiente alimentação". "Objeção: não sou invisível para os pássaros, os lagartos, as ratanzanas, os mosquitos"; c) que os veranistas sejam "seres de outra natureza"; d) ter enlouquecido e estar num manicômio; e) que "os intrusos sejam um grupo de mortos amigos" e ele "um viajante, como Dante ou Swedenborg, ou se não outro morto, de outra casta, num momento diferente da metamorfose" (51-2). A confissão feita por Morel aos veranistas e testemunhada clandestinamente pelo narrador produz uma reviravolta no regime explicativo ao revelar (parcialmente) o mistério pela via do estranho (revelação à qual se soma essa revelação suplementar constituída pela transcrição dos papéis de Morel, o que introduz novamente uma duplicação ou representação en abîme: o manuscrito dentro do manuscrito, a confissão dentro da confissão). ${ }^{11}$ De fato, embora não abunde em explicações pormenorizadas, a solução proposta é da ordem da utopia (ou do pesadelo?) tecnológica, por assim dizer, não da intervenção de um deus ex machina. ${ }^{12}$ Dessa perspectiva, inclusive, reafirma-se enfaticamente a impossibilidade de uma criação ex nibilo: "Para fazer reproduções vivas, necessito emissores vivos, não crio vida", sustenta Morel, o que distancia 
Faustine da série de autômatos femininos engendrados pela tradição fantástica, sem deixar de inscrevê-la ao mesmo tempo nessa tradição como contrafigura.

Entretanto, uma vez desvendado o mistério das aparições e desaparições súbitas, dos atos repetidos e, o que é mais importante ainda para o narrador, da indiferença de Faustine, a resposta alcançada volta a metamorfosear-se em enigma: em que medida é possível afirmar que essas "reproduções perfeitas" (essa ilusão perfeita proposta aos sentidos) "possuem alma"?; até que ponto são "pessoas reconstituidas que aparecem e desaparecem cada vez que se conecta ou desconecta o projetor" e não meros "simulacros de pessoas"?; qual é a relação instaurada entre o indivíduo gravado e o reproduzido?; qual dos dois é realmente?; a reprodução idêntica do sujeito duplica sua identidade, cinde-a, a usurpa?; quem é e onde está a autêntica Faustine?

A elucidação de um mistério manifesto, o do registro do fantástico, cede lugar a outro latente, que se desenvolverá em dois tempos.

Em seus papéis, depois de descrever o triplo mecanismo destinado a captar, gravar e projetar as sensações visuais, auditivas, táteis, olfativas e gustativas suscitadas pelo indivíduo captado (capturado?) por sua invenção, Morel afirma, entre outras coisas, o seguinte: "Depois de muito trabalho, ao congregar esses dados de maneira harmônica, encontreime com pessoas reconstituídas, que desapareciam se eu desligava o aparelho projetor; só viviam os momentos passados quando da tomada da cena e, ao concluí-los, voltavam a repeti-los, como se fossem partes de um disco ou de um filme que, ao terminar, voltasse a começar, mas que, para ninguém, podiam distinguir-se das pessoas vivas... Se atribuímos a consciência, e tudo o que nos distingue dos objetos, às pessoas que nos rodeiam, não poderemos negá-la às criadas por meus aparelhos, com nenhum argumento válido... Congregados os sentidos, surge a alma. [...] 
A hipótese de que as imagens tenham alma parece confirmada pelos efeitos de minha máquina sobre as pessoas, os animais e os vegetais emissores" (62-3). Da mesma forma, num trecho posterior, depois de ter confessado a seus hóspedes que tomou a liberdade de filmá-los sem anunciar o projeto, a fim de garantir a espontaneidade da gravação, Morel declara: "Aqui estaremos eternamente - embora amanhã vamos embora - repetindo consecutivamente os momentos da semana e sem poder sair nunca da consciência que tivemos em cada um deles, porque assim captaramnos os aparelhos; isso nos permitirá sentir-nos numa vida sempre nova porque não haverá outras recordações em cada momento da projeção, que as tidas no momento correspondente da gravação" (65).

Inicialmente, o narrador concentra suas energias especulativas na refutação das hipóteses morelianas, na afirmação do caráter fantasmagórico e segundo das imagens. Imagens que "não estão vivas", que não o estariam mesmo que se inventasse uma série de aparelhos destinados a continuar a empresa: "Assombra que a invenção tenha enganado o inventor. Eu também acreditei que as imagens viviam; mas nossa situação não era a mesma. Morel tinha imaginado tudo; tinha presenciado e conduzido o desenvolvimento de sua obra; eu a encontrei concluída, funcionando [...]. Razões lógicas nos autorizam a descartar as esperanças de Morel. As imagens não vivem. Entretanto, parece-me que tendo este aparelho, convém inventar outro, que permita averiguar se as imagens sentem e pensam (ou, pelo menos, se têm os pensamentos e as sensações que tiveram os originais durante a exposição [...] O aparelho, muito parecido com o atual, estará dirigido aos pensamentos e às sensações do emissor... E, algum dia, haverá um aparelho ainda mais completo. O pensado e o sentido na vida - ou nos momentos de exposição - será como um alfabeto com o qual a imagem continuará compreendendo tudo [...] A vida será, pois, um depósito da morte. Mas nem então a imagem estará viva; objetos essencialmente novos não existirão para ela [...] $\mathrm{O}$ fato de não podermos compreender nada fora do tempo e do espaço..." (68-9). Paradoxalmente, porém, ao mesmo tempo que se constata que a 
imortalização da repetição não é a imortalização da vida mas da morte, que as reproduções estão destituídas de ânima, a engrenagem da repetição (no sujeito) volta a ser posta em funcionamento.

Com efeito, superada a "repulsão" inicial pelas imagens, estas passam a se oferecer como objetos de "distração" aparentemente inócuos. Torna-se a espiar, a imiscuir-se, e se é um voyeur cada vez mais intrépido, realimentando (sem notá-lo) a ilusão:

Estou me acostumando a ver Faustine sem emoção, como se fosse um simples objeto. Por curiosidade, a sigo há uns vinte dias. Tive poucas dificuldades, embora abrir as portas - mesmo as que não estão fechadas a chave - seja impossivel (porque, se estavam fechadas quando se gravou a cena, tem de estar fechadas quando se projeta). [...] Faustine, ao recolher-se a seu quarto, fecha a porta. Numa só ocasião não me será possivel entrar sem tocá-la: quando a acompanham Dora e Alec. Depois, os dois saem rapidamente. Essa noite, na primeira semana, fiquei no corredor, diante da porta fechada e do buraco da fechadura, que mostrava um setor vazio. Na semana seguinte quis ver de fora e caminhei pela cornija, com perigo, ferindo as mãos e os joelhos contra a aspereza das pedras, que abraçava assustado... As cortinas impediram-me de ver. Na próxima ocasião vencerei o temor que me resta e entrarei no quarto com Faustine, Dora e Alec. Passo as outras noites ao lado da cama de Faustine, no chão, sobre uma esteira e comove-me vê-la descansar tão alheia ao costume de dormir juntos que vamos criando (67$8)$.

Durante dezessete dias vigiei. Nem um enamorado teria descoberto motivos para suspeitar de Morel e de Faustine. Não creio que Morel aludisse a ela no discurso... Mas, admitindo que Morel esteja apaixonado por Faustine, como é possivel afirmar que Faustine esteja apaixonada?... Na sala de jantar, uma noite, outra no hall, as pernas se tocam. Se admito a malicia, por que descarto a distração e o acaso? Repito: não há prova definitiva de que Faustine sinta amor por Morel. Talvez. a origem das suspeitas esteja em meu egoísmo. Amo a Faustine: Faustine é móvel de tudo... (69). 
A apenas um passo da idolatria, o sujeito dá forma a uma penúltima esperança que ganha os contornos de uma verdadeira Faustine, situada em outro lugar. Somente ela poderia oferecer a prova definitiva que se procura, desfazer a rede de falsas aparências, dar outro curso à história:

\footnotetext{
Sem conceder nada à minha fraqueza, posso imaginar a chegada emocionante à casa de Faustine, o interesse que sentirá por meus relatos, a amizade que essas circunstâncias ajudarão a estabelecer. Quem sabe se não estou verdadeiramente a caminho, longo e dificil, mas, a caminho, de Faustine... Mas, onde vive Faustine? Segui-a durante semanas. Fala do Canadá. Não sei mais (71).
}

De imediato o narrador "saberá mais", dado que, depois de ter ficado aprisionado na sala de máquinas e compreender o por quê, dará início a seus experimentos: "Primeiro fiz funcionar os receptores e os projetores... pus flores, folhas, moscas, rãs... Depois cometi a imprudência. Pus a mão esquerda diante do receptor [...] Os emissores vegetais - folhas, flores - morreram depois de cinco ou seis horas; as rãs depois de quinze. As cópias sobrevivem, incorruptíveis.... Quanto aos efeitos sobre a mão... tenho um ardor contínuo... caiu um pouco da pele" (75-6).

Tendo repetido os ensaios de Morel (tendo sido de algum modo seu duplo), o narrador volta a ler a confissão com outros olhos, com esse plus de saber (ou diferença) que resulta da possibilidade de reinterpretar $o$ mesmo, na letra, a partir da experiência vivida e de seus vestígios metamorfoseados em memória: "senti curiosidade diante do parágrafo do discurso de Morel... depois acreditei fazer uma descoberta.... Eis a frase que me assombrou: Terão de me desculpar esta cena, primeiro fastidiosa, depois terrível. Por que terrível? [...] É verdade que saber a posteriori que oito dias de nossa vida, em todos os seus pormenores, ficaram gravados 
para sempre, não deve ser agradável [...] Li de novo a frase: Terão de me desculpar esta cena, primeiro fastidiosa, depois terrível. Vamos esquecêla. Que significa isto? Que em breve não lhe darão importância ou que já não poderão recordá-la?.... a hipótese de que as imagens tenham alma parece exigir, como fundamento, que os emissores a percam ao ser tomados pelos aparelhos. O próprio Morel declara que a hipótese de que as imagens tenham alma parece confirmada pelos efeitos de minha máquina sobre as pessoas... [...] Mas tudo isto que deduro racionalmente significa que Faustine morreu, que não bá mais Faustine além desta imagem, para a qual não existo" (76).

Por um lado, o jogo das imitações parece cancelar-se sobre uma cópia sem modelo, uma reprodução sem original, um duplo que não duplica nada, pois é o único que existe. Por outro, o jogo imitativo prolonga-se na tentativa de compreender-se através do inventor-artífice que até agora fora concebido unicamente como rival, intruso, obstáculo, inimigo. De certa forma, poderia afirmar-se que o narrador migrou, em sua relação com Morel, da condição de oponente (imaginário) que o copia sem advertir à de cúmplice voluntário que o imita conscientemente e que, finalmente, vê-se nele:

\footnotetext{
Quero explicar-me a conduta de Morel. Faustine evitava sua companbia; ele tramou, então, a semana, a morte de todos seus amigos, para conseguir a imortalidade com Faustine. Com isso compensava a renúncia às possibilidades que há na vida... Mas a própria indignação que sinto me põe em guarda. Talvez atribua a Morel um inferno que é meu. Eu sou o apaixonado por Faustine; o capaz, de matar e matar-se [...] A beleza de Faustine merece essas loucuras, essas homenagens, esses crimes... Agora vejo o ato de Morel como um justo ditirambo (79-80).
}

Nada mais "razoável”, pois, ao atingir esse ponto, que renunciar "às esperanças de partir à procura de Faustine" e que "acomodar-se ao destino seráfico de contemplá-la". Mas dado que "a condição da felicidade [do narrador], como tudo o que é humano, é instável”; que "a con- 
templação poderia interromper-se", se tornará necessário morrer para não morrer [...] quase exatamente igual ao modelo. ${ }^{13}$

Estou a salvo dos intermináveis minutos necessários para preparar minha morte num mundo sem Faustine; estou a salvo de uma interminável morte sem Faustine. Quando me senti disposto liguei os receptores... Ficaram gravados sete dias. Representei bem: um espectador desprevenido pode imaginar que não sou um intruso. É o resultado natural de uma laboriosa preparação: quinze dias de ensaios e estudos... Estudei o que diz Faustine, suas perguntas e respostas; muitas vezes intercalo com habilidade alguma frase; parece que Faustine me responde... Espero que, de modo geral, demos a impressão de ser amigos inseparáveis, de nos entendermos sem necessidade de falar... (80).

Substitui os discos; as máquinas projetarão a nova semana, eternamente... $e$, se a imagem tem - como creio - os pensamentos e os estados de ânimo dos dias da exposição, o gožo de contemplar a Faustine será o meio em que viverei na eternidade.... (80).

Levar a representação e o fingimento até o limite da ilusão (quase) perfeita, do que parece real (e convidar o leitor a assumir o lugar do "espectador desprevenido" que vê o que não é, que crê no que parece). Uma vez apreendida a lógica de Morel, o narrador pode entregar-se por inteiro a uma idolatria mortífera, embora sentida como benéfica, que é descrita deste modo:

Quase não sinto o processo de minha morte; começou nos tecidos da mão esquerda... prosperou muito... Perco a vista. O tato tornou-se impraticável; cai-me a pele; as sensações são ambiguas, dolorosas; procuro evitá-las... A persistente, a infima ansiedade pelas relações de Morel com Faustine preserva-me de atender à minha destruição; é um efeito inesperado e benéfico... Desgraçadamente, nem todas as mi- 
nhas cavilações são tão úteis: há - somente na imaginação, para inquietar-me - a esperança de que toda minha doença seja uma vigorosa auto-sugestão; que as máquinas não façam mal; que Faustine esteja viva e dentro em pouco, eu vá procurála; que nos riamos juntos destas falsas vésperas da morte [...] Ainda vejo minha imagem em companhia de Faustine. Esqueço-me de que é uma intrusa; um espectador não prevenido poderia julgá-las igualmente apaixonadas e dependentes uma da outra. Talvez este parecer exija a debilidade de meus olhos. De qualquer maneira consola-me morrer assistindo a um resultado tão satisfatório. Minha alma não passou, ainda, para a imagem; se não, eu teria morrido, teria deixado de ver (talvez) Faustine, para estar com ela... (81-2).

De fato, se o relato se concluísse aqui, apesar da sofisticação da trama, o leitor de La invención estaria sendo convidado a permanecer no lugar de "espectador não prevenido", a crer cegamente na imagem que lhe é mostrada. Ocorre que o último parágrafo, ao proferir uma súplica, imprime uma mudança fundamental: desmascara as ilusões anteriormente construídas sem desmentir, porém, o caráter necessário da ilusão do sujeito, da necessária ilusão de ser sujeito para alguém:

\footnotetext{
Ao homem que, baseando-se neste informe, invente uma máquina capaz de reunir as presenças desagregadas, farei uma súplica. Busque-nos, a Faustine e a mim, faça-me entrar no céu da consciência de Faustine. Será um ato piedoso.
}

Coda:

$\mathrm{Na}$ sua ambivalência, a palavra identidade remete simultaneamente ao singular, o diferente, o irrepetível e ao reiterado, o igual, o idêntico. Que o sujeito se estruture por imitação, repetição e cópia de outros sujeitos, mas que para constituir-se necessite do reconhecimento, por parte desse(s) outro(s), de sua condição de uno, de singular, de irrepetível, é uma das expressões dessa ambivalência (que constitui, por outro lado, a inscrição, na língua, de uma subjetividade histórica: a nossa, a de uma mo- 
dernidade talvez em vias de desaparição). Se chega a ser uno (uno dividido, é claro), conquista-se uma identidade (a referência à sedução e ao combate não é gratuita), por intercessão de um outro. No entanto, tratase de uma conquista incerta, insegura, que solicita permanentemente ser reconfirmada, e que além do mais não livra o sujeito da inquietante pergunta pelo lugar (a residência) e pela durabilidade de um bem a um tempo tão precioso e tão precário.

Desde finais do século XVIII um vasto conjunto de narrações fantásticas, de ficções científicas e de manifestações conjugadas deu forma a essa questão que norteou, também, no campo teórico, grande parte do discurso psicanalítico. Duplos e desdobramentos de toda classe foram imaginados ao longo desse processo com o propósito de interrogar a identidade do ser, muito amiúde, do ser desejado. Nessa trajetória, La invención de Morel, primeiro termo, por sua vez, de uma série de ficções criadas por Bioy Casares, que rondam de diferentes perspectivas o mesmo assunto (lembremos somente das mais memoráveis: Máscaras venecianas, El lado de la sombra, Los milagros no se recuperan, Dormir al sol) ocupa uma posição privilegiada. As presentes notas de trabalho constituem um primeira aproximação à referida problemática em sua obra.

\section{Notas}

$1 \mathrm{O}$ procedimento adotado nestas notas de trabalho apóia-se em alguns princípios barthesianos explicitados, entre outras obras do crítico, em seu $S / Z$ (Paris: éd. du Seuil, 1973). Menciono sinteticamente os mais importantes: a idéia de que o comentário é uma forma de "jogar sistematicamente com a digressão (forma mal integrada ao discurso do saber)" ; a de que comentar passo a passo um texto, evitando estruturá-lo em demasia, é "renovar suas entradas"; a idéia dos cortes operados no objeto como constituindo já operações de leitura. Nesse sentido cabe advertir que as recorrentes citações do romance, embora literais, com freqüência recompõem (por decomposição) o texto tutor, ao aproximar parágrafos distantes entre si. 
2 Bioy Casares, A. La invención de Morel (1940). In La invención y la trama (Pichon Rivière, M., org.). Barcelona: Tusquets, 1992. O número indicado entre parênteses corresponde à numeração da página. Há uma edição portuguesa do romance ( $A$ invenção de Morel. Rio de Janeiro: Rocco, 1986). Apesar de tê-la consultado para a redação destas notas preferi retraduzir as passagens citadas com base na edição de Tusquets.

3 De uma perspectiva vinculada a preocupações de ordem clínica Didieu Anzieu aborda alguns aspectos do romance de Bioy Casares em "Machine à décroire: sur un trouble de la croyance dans les états limites" (Nouvelle Revue de Psycanalyse, No 18, 1978), ensaio no qual retoma suas reflexões acerca do Eu-pele externo e do Eu-pele interno, ou seja, da existência de uma "dupla pele psíquica". Embora a ordem de interrogações que se pretende abordar no presente trabalho não seja alheia ao que grosso modo cabe denominar de discurso psicanalítico, trata-se de uma indagação centrada nas peripécias e nos modos de organização do relato, não em seu poder de ilustração de transtornos observáveis no âmbito da clínica.

4 Sobre a relação entre leitura e voyeurismo cf. Green, A. "A desligação” (1971). In Lima, L. C., org Teoria da Literatura em suas fontes. Vol I. Rio de Janeiro: Francisco Alves, 1978. 5 Sobre a inscrição do romance na tradição da literatura pastoril e utópico/distópica, de Tomás Moro a Júlio Verne, G.H. Wells e suas respectivas ilhas, cf. o livro de Suzanne Levine, Guia de Bioy Casares (Madri: Editorial Fundamentos, 1982).

6 O tópico do olhar como indício da natureza ou estatuto do sujeito também é central no intertexto mais evidente do romance de Bioy: A ilha do Dr. Moreau, de G.H. Wells. Entretanto, trata-se de entoações substancialmente diferentes de um mesmo tema. $\mathrm{Na}$ ficção de Wells, Prendrik, o narrador-protagonista, observa insistentemente as criaturas da ilha devido à aparência estranha destas, estranheza atribuível a uma condição semianimal descoberta à medida que se desenvolve a trama. As criaturas, por sua vez, espionam insistentemente a Prendrik (que se sabe observado) durante seus passeios e, mais tarde, durante sua tentativa de fuga. Ao longo dessa vigilância mútua desponta um leit motiv: o da luminosidade noturna que caracteriza os olhos dos seres produzidos por Moreau, signo revelador de natureza bestial, não plenamente humana. Em La invención, o olhar unilateral, hierático e de certo modo opaco, denunciará a longo prazo a autênti- 
ca condição de Faustine, apesar de ser inicialmente objeto de uma interpretação "errônea" indispensável para o desenvolvimento da narrativa.

7 De fato, as sucessivas posições assumidas pelo sujeito (fugitivo, investigador, enamorado) correspondem a outros tantos códigos genéricos que vão urdindo simultaneamente a identidade do texto.

8 A premissa psicanalítica sobre o caráter mediado e imitativo do desejo ou, em outras palavras, sobre a presença sine qua non de um terceiro (não necessariamente real) em sua gênese, tem sido habilmente aproveitada no marco de uma reflexão teórica sobre o gênero romanesco por René Girard, em Mensonge romantique et verité romanesque (Paris: Grasset, 1961). Contra esta verdade, à qual as grandes obras aludiriam, ergue-se a mentira romântica que proclama o caráter espontâneo e direto do desejo. A pretensão de originalidade do sujeito romântico conduz a ver o mediador como rival a ser suprimido e não como aquilo que é, um modelo secretamente (e amiúde inconscientemente) venerado. As diversas fases da relação entre o narrador-protagonista e Morel ("o horroroso tenista" desta cena) podem ler-se em boa medida nesta chave. Evidentemente, semelhantes premissas operam não só no plano da intriga amorosa (e fantástica) representada, mas no plano da escrita: "apaga-se" (qual rival a suprimir) e emula-se (qual modelo a secundar) um conjunto de textos que vão do já mencionado de Wells a Morella de Edgar Allan Poe, dentre outros.

9 Vários dos atos empreendidos pelo protagonista instauram uma oposição entre o espontâneo ou não premeditado como fonte potencial de diferença e o premeditado ou ensaiado como ritual repetitivo que conduz à morte. Isso, apesar da recorrência que acabam ganhando as ações "improvisadas", sempre endereçadas ao mesmo objetivo: ser reconhecido pela mulher.

10 Cf., entre outros, Vax, L. La séduction de l'étrange. Paris: PUF, 1965. Todorov, T. Introdução à literatura fantástica. São Paulo, Perspectiva, 1975. Malrieu, J. Le fantastique. Paris, Hachette, 1992 e Jordan, M.E. La narrativa fantástica. Frankfurt-Madrid, Vervuert/Iberoamericana, 1998.

11 Relecapitulemos sumariamente o conteúdo dessa primeira revelação: os habitantes da ilha, incluídos Faustine e o próprio Morel, são uma espécie de "imagens holográfi- 
cas", filmadas por um complexo dispositivo que entra em funcionamento periodicamente, com a subida das marés, e as projeta.

12 A imaginação do que poderia denominar-se de "estado limite da reprodução" é indissociável de um desenvolvimento tecnológico que alterou significativamente a percepção humana e no qual a invenção de diversos instrumentos ópticos teve um papel fundamental, como demostrou Max Milner em La fantasmagorie (Paris: PUF, 1982). Sem a existência da fotografia e do cinema a título de experiências generalizadas e decisivas para a configuração de certa subjetividade histórica, um romance como o de Bioy, publicado em 1940, vale a pena lembrar, resulta inconcebível.

13 Evidentemente, todo um conjunto de afirmações realizadas pelo narrador, tanto com respeito a si mesmo como com respeito a Morel, tem trocado de signo ou metamorfoseado seu valor nessas alturas. Cito tão somente duas: "Toda esta higiene de não esperar nada é um pouco ridícula. Não esperar da vida para não arriscá-la; dar-se por morto para não morrer"; "Assombra que o invento tenha enganado o inventor. Eu também acreditei que as imagens viviam, mas nossa situação não era a mesma".

\section{Bibliografia}

Anzieu, D. "Machine a décroire: sur un trouble de la croyance dans les états limites". Nowvelle Revue de Psychanalyse, № 18, 1978, pp. 151-167.

Camurati, M. Bioy Casares y el alegre trabajo de la inteligencia. Buenos Aires: Corregidor, 1990.

Green, A. (1970) "Literatura e psicanálise: a desligação". In Lima, L. C., org Teoria da Literatura em suas fontes. Vol I. Rio de Janeiro: Francisco Alves, 1978.

Girard, R. Mensonge romantique; verité romanesque. Paris: Grasset, 1972.

Jordan, M. E. La narrativa fantástica. Frankfurt-Madrid: Vervuert/Iberoamericana, 1998.

Levine, S. Guía de Bioy Casares. Madrid: Fundamentos, 1982.

Malrieu, J. Le fantastique. Paris: Hachette, 1992

Todorov, T. (1970) Introduşão à literatura fantástica. São Paulo: Perspectiva, 1975.

Vax, L. La séduction de l 'étrange. Paris: PUF, 1965.

Revista La maga. Homenaje a Bioy, No 19, 1996. 